\title{
Marie. Overleven met de dood
}

\author{
Marie Bamutese, Peter Verlinden
}

Davidsfonds, Leuven, 2015

Het verhaal van Marie, toen een jong meisje, is het verhaal van de meer dan twee miljoen Rwandese vluchtelingen. Eerst had je de interne vlucht, in Rwanda zelf, vanaf april I994; een beetje later kwam daar de vlucht naar het Congolese regenwoud, vanaf oktober I996, bij. Hun vluchtelingenkampen in Oost-Congo werden toen aangevallen door het Rwandese regeringsleger van de huidige president Paul Kagame. Zijn militairen maakten maandenlang jachtop de vluchtelingen en moordden hen voor het grootste deel uit: meer dan 200.000 doden volgens een expertenrapport van de Verenigde Naties, het dubbele of meer volgens ooggetuigen, ook volgens Marie die als bij wonder de dood overleefde. Met de woorden van het boek: 'Het Congolese regenwoud herbergt een van de grootste misdaden tègen de mensheid van het einde van de $20^{\circ}$ eeuw. Terwijl de wereld het wist en zweeg en tot vandaag grotendeels blijft zwijgen'. De cijfers zijn wellicht inderdaad onderschattingen. Bovendien heeft de Rwandese genocide die volgde op het neerhalen van het vliegtuig naar schatting I tot 2 miljoen slachtoffers gemaakt. Hallucinant (zie onder andere: http://survivors-fund.org.uk/resources/rwandan-history/statistics/ voor gedetailleerde info).

Op 6 april 1994 werd een vliegtuig met daarin de Rwandese president Juvénal Habyarimana (een Hutu) en de president van Burundi, Cyprien Ntaryamira (ook een Hutu, die amper 2 maand in functie was), neergeschoten tijdens de voorbereiding om te landen in Kigali. Beide presidenten stierven toen het vliegtuig neerstortte. De presidenten reisden samen in het toestel van Rwanda omdat het toestel van Burundi "toevallig" stuk was geraakt. Eigenaardig was het feit dat een Burundees reeds plaats nam in het Rwandees toestel alvorens het defect werd gemeld. Beide toestellen waren een geschenk van de Franse president en werden door Frankrijk onderhouden. Meteen na de moord op president Habyarimana, op de avond van 6 april 1994, wierpen soldaten en militieleden gelijk barricades op rond Kigali. Nog voor de ochtend van 7 april waren de presidentiële 
garde en de milities al begonnen met het vermoorden van Tutsi's en van Hutu's die bekendstonden als voorstanders van de Arusha-akkoorden. De moord op de president, de minister-president en een aantal ministers bood ruimte aan extremistische politici om hun posities over te nemen in een interim-regering onder regie van kolonel Theoneste Bagosora. En tevens vormde dit het begin van een genocide van ongekende afmetingen en gruwel. Iedereen moordde iedereen uit. Elkeen had blijkbaar wel een 'goeie' reden. Behalve de door propaganda ingeboezemde haat en angst waren er ook daders die uit conformisme of opportunisme handelden. Woningen van slachtoffers werden geplunderd of in bezit genomen. Voor werk- en landloze jonge mannen was het de enige manier om een stukje grond te bemachtigen. Soms werden ze gedwongen deel te nemen in het kader van Umuganda, gemeenschapswerk. Zo dekten de aanstichters zich in door medeplichtigen te maken en een collectieve schuld te creëren. De genocide eindigde op I8 juli met de overwinning van het RPF, het Rwandees Patriotisch Front onder leiding van huidig president Kagame, en de vlucht van de interim regering, de milities en het leger naar de omliggende landen. In de vluchtelingenkampen maakten de extremisten echter de dienst uit en zou de terreur nog een tijd worden voortgezet. Over de aantallen daders en slachtoffers bestaat meer dan twintig jaar na dato nog steeds discussie. Dat komt in de eerste plaats door onduidelijkheid over het werkelijke percentage Tutsi's dat bij volkstellingen te laag zou zijn gerapporteerd. Op basis van wetenschappelijk onderzoek zijn de volgende ruwe schattingen aannemelijk gemaakt. Van de Tutsi's die tijdens de genocide in Rwanda woonden is 70 à $75 \%$ vermoord. De percentages verschillen per regio en lopen uiteen van $50 \%$ tot $90 \%$. In totaal zou het gaan om rond de 675.000 slachtoffers van genocide. Daarnaast is een onbekend aantal Hutu's om het leven gekomen of nooit teruggekeerd uit ballingschap. Naast de Hutu-slachtoffers van milities, zo'n 50.00o, zijn ook duizenden Hutu's omgekomen bij gevechten of door wraakacties van het RPF.

Alle autoriteiten in de hele wereld, ook de Europese en de Belgische, waren perfect op de hoogte van wat er eerst in Rwanda zelf gebeurde, en van het menselijk drama in de wouden van Congo nadien. Niemand heeft ingegrepen. Een halfslachtig-opportunistisch (tot hypocriet) excuus (zeg maar knieval) van Belgische eerste minister Verhofstadt leek eerder een geval van gewetensusserij dan dat er een gemeend gevoel uit sprak: op gevaar af een en ander op flessen te trekken zou je je kunnen afvragen waarom België zich moest verontschuldigen voor het feit dat een regime (dat van Kagame) dat zélf boter op zijn hoofd heeft ro Belgische militairen had doodgeschoten. Hallucinant, deel 2.

Uiteindelijk kon en kan het Rwandese regime, dat met internationale steun nog altijd aan de macht is, vrij zijn gang gaan. Dit is een van de grootste bewust 'vergeten' misdaden tegen de mensheid van de 20 ste eeuw. En we blijven volharden in de boosheid. Maar ja, Kagame handelt in coltan, en andere mineralen en die schijnen, tot nader orde, van 'levensbelang' te zijn, en dus... doen wij, in het westen 'graag' water in onze wijn?! Coltan is een erts dat de mineralen columbiet en tantaliet bevat; uit coltan worden de elementen niobium (vroeger columbium geheten) en tantaal gewonnen. De beide stoffen kennen veel industriële toepassingen. Tantaal wordt onder andere in poedervorm gebruikt bij de productie van kleine elektrolytische condensatoren (tantaal-elco's), die worden gebruikt 
in mobiele telefoons, spelcomputers, pc's, laptops en andere elektronische apparaten waarin kleine elco's nodig zijn. De gewapende conflicten die al jaren verdersudderen in het grensgebied van de Democratische Republiek Congo en Rwanda, worden door beide partijen deels met illegale handel in coltan en bloeddiamanten gefinancierd. Hoewel veel fabrikanten er aanvankelijk naar streefden om het erts zo goedkoop mogelijk te verkrijgen, desnoods uit omstreden gebieden en wildreservaten waar gorilla's met uitsterven bedreigd worden, eisen de meeste afnemers tegenwoordig een verklaring dat alleen legale bronnen zijn gebruikt - dream on, denk je dan...

Het verhaal dat Peter Verlinden en Marie hier brengen, speelt zich af tegen deze moorddadige achtergrond. In hun relaas overstijgen ze het puur persoonlijke en individuele. De auteurs brengen een doorleefd verhaal aangevuld met referenties aan bredere context. Een persoonlijk verhaal als aanzet tot geschiedschrijving. Bovendien slagen zij er wonderwel in om hun eigen politieke insteek en voorkeur in deze niet al te blattant op de voorgrond te tillen. Zie gelijk de opdracht: 'voor de verantwoordelijke politieke leiders, om het belang van de mens boven het belang van de macht te stellen'. Zoals uit de alinea's hierboven blijkt, had ondergetekende een meer tendentieuze opdracht kunnen bedenken. Het is lofwaardig - vind ik - hoe objectief-ingetogen Verlinden doorgaans zijn/Marie's verhaal brengt. De toon is meestal factueel, maar het relaas steunt wel op waar gebeurde verhalen, al of niet verdrongen herinneringen, nachtmerries, ... zodat er af en toe geïnterpreteerd wordt. Sommigen zullen de woordkeuzes hier en daar tendentieus vinden, maar: laat ons wel wezen: de 'rebellen' van Kagame waren geen koorknapen, en liggen wellicht mooi (nu ja) in evenwicht met de moordbendes (sic) aan Hutu-kant. Anderen zullen dan weer opmerken dat de auteurs selectief met een (te?) beperkte set bronnen werken om Marie's verhaal te duiden. So be it, zou ik zeggen. Dit is een emotioneel, op persoonlijke feiten gebaseerd verhaal; fictie geen wetenschap (de cijfers kloppen niet altijd, of zijn niet altijd even duidelijk); de allerindividueelst expressie van gevoelens en emoties. We beléven de genocide en wat volgde doorheen de verhalen van Marie. Details, taferelen, gevoelens van angst en onmacht, de kleine dingen,... laten ons dit immense drama bijna dag aan dag meebeleven. En dat is een grote verdienste! Laat mij hier ook nog aan toevoegen dat het niet altijd evident blijkt te zijn om uit de wetenschappelijke literatuur ter zake de objectieve 'waarheid' te destilleren: net zoals je wetenschappers hebt die (al of niet betaald door de industrie) met een uitgestreken gezicht verkondigen dat tabak niet verslavend werkt, zo heb je ook (al of niet bonafide) wetenschappers die in verband met de Rwandese genocide bepaalde cijfers negeren, weinig-objectieve standpunten innemen,... Wij zijn deze beide auteurs erkentelijk om dit niveau te overstijgen, vermits hun verhaal getekend is door jaren van kwalijke ervaringen, gruwel en pijn?

Of we nu willen of niet: we worden meegezogen in dit verhaal van barbarij en onaanvaardbaar geweld. De auteurs kiezen duidelijk partij, hoe kan het anders, betrokken als ze zijn bij wat er gebeurd is. Blijkbaar valt de wereld (en vooral de Belgische wereld) uiteen in Hutu- dan wel Tutsi-lovers. Je bekennen tot één van beide kampen lijkt je een moreel gelijk te geven. Maar, laat ons echter duidelijk zijn: niets, maar dan ook niets, kan dit soort moordpartijen verantwoorden. Het boek kiest af en toe, al of niet openlijk, 
partij voor het eigen volk, het eigen gelijk, maar: kan je Marie ongelijk geven? Doordat het boek op vele plaatsen de anekdotiek, de eigen, persoonlijke gevoelens overstijgt, vormen die de aanleiding om inzicht te krijgen in de bredere geschiedenis, de achtergronden, beweegredenen,... van het land en zijn regio. Vanuit de gruwel, de vraag naar Catharsis, vrede,... : 'het leed van de ene kan nooit het leed van de andere in de schaduw zetten. Pas als ieders leed erkenning krijgt, pas als al de Rwandezen samen kunnen rouwen [-] dan pas kan Rwanda bouwen aan een echte toekomst'. Het is spijtig dat etnische betrokkenheid het eerste goddelijke gebod: 'gij zult niet doden' in de weg staat. Ik zei het al: je bekennen tot een van beide etnische groepen, lijkt een vrijbrief om de genocide, de moordpartijen, het eigen gelijk,... goed te praten. Not in my book! En ook niet in dit boek...

Bij uitbreiding wordt het verhaal van Marie, dat van Mohammad, Samir,... van alle mensen die op de vlucht zijn voor geweld en uit de hand gelopen dikwijls politiekgestuurde conflicten met doorgaans een plat-economisch-financiële aanleiding. In die zin, blijft het boek brandend (pun not intended) actueel. Leer ze ons kennen, de Kagames, Poetins, Assads,... Trumps ... van deze wereld. Meedogenloos gaan dit soort losgeslagen idioten in tegen alle menselijkheid. Nietsontziend eigenbelang, cynische machtshonger kosten dagelijks duizenden levens, but: who cares? Zeker niet de hierboven genoemden ! Doden dienen belangen waar gewone stervelingen niet bij kunnen. Marie is wat dit betreft 'gewoon' een van de velen. Gelukkig gaf zij zichzelf, en via Peter Verlinden, een stem. Hopelijk reikt die stem ook tot die die vinden dat de Tutsi's alle redenen hadden om terug te slaan, dat deze of gene méér gelijk had...

Marie Bamutese getuigt over haar eigen overlevingstocht en die van haar familie, over de dood van haar vader, moeder, groøtmoeder, neven en nichten, tantes en nonkels, jeugdvrienden en vriendinnetjes, over het slechtste in de mens, maar ook over haar geloof dat haar de kracht gaf om te blijven leven en over die enkele helden dankzij wie ze vandaag nog leeft. 'Velen blijven zwijgen', staat er, 'omdat ze vrezen dat hun familie in Rwanda te kwetsbaar is, omdat ze vrezen dat niemand hen zal geloven, omdat het leed zo diep zit dat erover praten, getuigen te pijnlijk blijft'. Marie, echter, wil spreken omdat alleen de waarheid gerechtigheid kan brengen - in de context van Marie's verhaal mag dat verhaal gekleurd zijn. En alleen gerechtigheid kan verzoening brengen..

Het verhaal van Marie begint tijdens een rustige paasvakantie samen met haar familie in Ngenda, een plattelandsgemeente in de Bugesera, een streek ten zuiden van de Rwandese hoofdstad Kigali. De gezapigheid van het dorpsleven wordt ruw verstoord als op 7 april 1994 de genocide tegen de Tutsi's begint. Twee weken later trekken enkele verslagen legereenheden door Ngenda. Als de familie geruchten opvangt over massale wraakacties door het RPF (het Tutsi-geleide Rwandees Patriottisch Front) slaat de paniek toe. Ze besluiten alles achter te laten en halsoverkop te vertrekken. Het eerste deel van Marie's vlucht gaat in westelijke richting, dwars door streken waar de genocide in volle gang is. Marie ziet onderweg een paar open massagraven met gruwelijk verminkte lijken van Tutsi's. Bij een wegversperring wordt ze bijna zelf het slachtoffer van de Interahamwe (paramilitaire Hutu-organisatie, verwant aan het regime van de vermoorde president) als de militieleden haar voor een Tutsi aanzien. Kordaat optreden van haar moeder redt 
Marie van een wisse dood. Ze is dan al meegesleept naar de rand van een put vol lijken en bloed. De familie kan een paar maanden later de grens met Zaïre oversteken. Ze raakt in groepjes verspreid over vluchtelingenkampen in de buurt van de steden Bukavu en Goma, waar ze twee jaar zullen blijven. In het najaar van I996, als de eerste Congo-oorlog uitbreekt, komt het kamp van Marie onder vuur te liggen. Samen met haar moeder, oma en een paar andere familieleden vlucht zij de jungle in. Negen maanden van zware ontberingen volgen totdat ze het oerwoud durven te verlaten en in Goma terechtkomen. De oma en een nichtje hebben de tocht niet overleefd. Terugkeren naar Rwanda durft Marie niet meer vanwege de aanhoudende geruchten over wraakacties. In I998 lukt het uiteindelijk om met valse papieren naar Kenya, en daarna naar Europa, te ontkomen.

Ik beveel dit boek dus graag aan aan wie een inzicht wil verwerven in de brede problematiek van 'de vluchteling' en in die van de Rwandese genocide in het bijzonder.

\section{Marie. Surviving with death}

This book brings us the story of Marie, who was a young girl when the Rwanda genocide crisis broke out in I994. The book is the result of a number of conversations between Marie and Peter Verlinden, the main co-author. The work is a very personal and personalised account of what happened on and after April 6. It starts with the internal flight, within Rwanda, and the journey to the Congolese rainforest, starting in October 1996. This was the moment when the refugee camps in eastern Congo were attacked by the Rwanda army of president Paul Kagame. It has been documented that his soldiers chased down and killed the majority of refugees, numbering more than 200,000 according to a report by the United Nations. According to survivors and other eye witnesses the actual number was probably double that.

The Rwandan genocide, known officially as the genocide against the Tutsi, was a genocidal mass slaughter of Tutsi in Rwanda by members of the Hutu majority government. An estimated 500,000-I,000,000 Rwandans were killed during the Ioo-day period from April 7 to mid-July I 994 , constituting as many as $70 \%$ of the Tutsi and $20 \%$ of Rwan$\mathrm{da}$ 's total population. The genocide and widespread slaughter of Rwandans ended when the Tutsi-backed and heavily armed Rwandan Patriotic Front (RPF) led by Paul Kagame took control of the country. An estimated 2,000,000 Rwandans, mostly Hutus, were displaced and became refugees. On April 6, I994, an airplane carrying Habyarimana, Rwanda's president, and Burundian president Cyprien Ntaryamira was shot down on its descent into Kigali. At the time, the plane was in the airspace above Habyarimana's house. One person survived but died soon after en route to the hospital.

The assassination of Habyarimana ended the peace accords that had been reached just before the incident. Genocidal killings began the following day. Soldiers, police, and militia quickly executed key Tutsi and moderate Hutu military and political leaders who could have assumed control in the ensuing power vacuum. Checkpoints and barricades were erected to screen all holders of the national ID card of Rwanda (which contained ethnic classification information introduced by the Belgian colonial government in I933) 
in order to systematically identify and kill Tutsis. These forces recruited and pressured Hutu civilians to arm themselves with machetes, clubs, blunt objects, and other weapons to rape, maim, and kill their Tutsi neighbours, and to destroy or steal their property. The breakdown of the peace accords led the RPF to restart its offensive, rapidly seizing control of the northern part of the country before capturing Kigali in mid-July, bringing an end to the genocide. During these events and in the aftermath, the United Nations(UN) and countries including the United States, the United Kingdom, and Belgium were criticized for their inaction and failure to strengthen the force and mandate of the UN Assistance Mission for Rwanda (UNAMIR) peacekeepers. Other observers criticized the government of France for alleged support of the Hutu government after the genocide had begun.

This is the kind of overarching official narrative to be found in history books (in this case, information was obtained from the relevant wikipedia page). This book, however, tells us about the genocide as seen by an innocent victim. It gives us the very personal view of a girl who was traumatized by the events, and interpreted what she saw and went through according to her own past and culture, her own norms and values. Do not expect an objective account. Instead you will be exposed to very personal observations and insights into the reality as she experienced it. The authors try to contextualize some of the events by giving some background information. Some will say that the latter is coloured by the authors' personal views and past, but that is not necessarily a weakness. What happened there and at that time is by any measure unacceptable! What remains then, is a compelling story about one of the most horrific events of recent decades. No more, no less. It helps us to understand not only Marie's plight, but also that of all refugees who are currently fleeing from conflict in countries such as Syria, Lybia, Afghanistan, Southern Sudan, and so on. As such this book is required reading for scholars, politicians and humanitarian organisations alike; a work for all those who want to know more about what it feels like to be unwanted and a fugitive, often in one's own country...

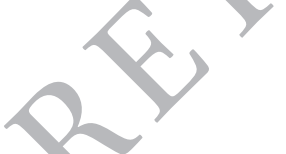

Patrick Van Damme

Laboratory for Tropical and Subtropical Agronomy and Ethnobotany, Ghent University 